\title{
Corporate Heritage Brand Traits and Corporate heritage brand identity: the case study of John Lewis Partnership
}

\begin{abstract}
Purpose: This paper studies the corporate heritage brand traits and corporate heritage brand identity by concentrating on developing key dimensions for the corporate heritage brand dimensions in the retailing industry in the UK. This study advances the corporate brand heritage theory and introduces the theory of corporate heritage brand identity which is developed from the Case Study of John Lewis - one of the most respected and oldest retails in the UK established in 1864.

Design/methodology/approach: This empirical study has adopted a theory building case study using qualitative data. It utilises semi-structured interviews that were organised and managed by John Lewis heritage centre in Cookham. Fourteen participants were involved in this study. The analysis of data was analysed using Nvivo.11 Software to set the main themes and codes for this study framework.

Findings: This study identifies Balmer's (2013) corporate heritage brand traits that are essential to be considered for the corporate heritage brands in the retailing industry to sustain their innovativeness and competitiveness. The findings of the case study informed the four dimensions of corporate heritage brand identity which include Price, Quality, Symbol and Design. The findings are incorporated into a theoretical framework of corporate heritage brand identity traits.
\end{abstract}


Practical implications: The discussed traits of this study can help brand senior management to enhance their corporate heritage reputation and sustainability through maintaining these (four) traits over their brand, and inform their brand stakeholders about their brand heritage success.

Originality/value: This is one of the few attempts to develop a research framework of corporate heritage brand identity. This framework suggests four dimensions of corporate heritage brand identity traits including brand price, quality, design and symbol. This is one of the first attempts to study corporate heritage branding management traits in the retailing industry sector.

Keyword: corporate heritage, brand traits, John Lewis, corporate heritage brand identity, retail.

Paper type: Research paper 


\section{Introduction}

This paper demonstrates and clarifies the theory of corporate heritage brand identity. Corporate heritage brand identity theory was introduced to reflect the brand story and roots, moreover, present longevity, reputation, experience and development of the corporate brand (Balmer et al., 2006; Urde et al., 2007). This study reflects the importance of Balmer's (2013) corporate heritage brand traits to enhance the brand position and reputation in the retail market. The paper examines the several corporate heritage brand characteristics which Balmer's paper "corporate heritage, corporate heritage marketing, and total corporate heritage communication: what are they? What of them?" discussed (Balmer, 2013). In addition to that, the study implements these six traits on the John Lewis brand case which extends the contribution of several researches by (Sammour et al. 2019; Sammour, 2017). The researchers aim in this study is to explore the importance of corporate heritage traits to build a brand identity; the study will investigate the measure factors which affect corporate heritage brand identity which is considered to be traits. The study results help the high- street retail heritage brand managers to test their brand identity using the finding dimensions to ensure sustainability in a competitive market. The brand managers need to give attentions for their brand identity as stakeholders demand and needs to keep changing to ensure reflecting their business ethos and their ability to deliver the best service to its customers all the time.

The past literature on corporate heritage brand identity does not implement Balmer's (2013) findings toward the importance of the corporate heritage traits to sustain the brand identity. While it was recommended to implement these traits and test their validity on one of the heritage brands, therefore, this paper explores the brand heritage traits of one of the most successful retail heritage brand traits and recognises that corporate heritage brand price, quality, design and symbol are essential to sustain its identity. Most of the previous studies concentrate on defining the relationship between brand and corporate heritage identity. Scholars reflect on the impact of brand in several fields such as royalty, tourism, family business, heritage and sociality. The paper investigates the corporate heritage brand identity dimensions from several perspectives such as price, quality, design and symbol (Sammour, 2017). The developed corporate 
heritage brand identity model is significant for researchers and practitioners in the retail field. To the researcher, the corporate heritage brand identity model can be a starting point for further empirical research. Additionally, this study is developed from the approaches that Balmer et al. (2006) and Urde et al. (2007) articles defend to build this theoretical base on corporate heritage brand identity. Urde and other researchers made use of the main five dimensions that define this theory (core values, use symbols, track record, longevity, and History) to a measurable item that represents the brand. The research finding clarifies the main dimensions which is adapted from Balmer (2013) heritage brand traits to be reflected on any high street retail corporate heritage brand.

This study is the first attempt to build an integrative vision of corporate heritage brand in a heritage high street origin. The model of this study will provide corporate heritage brand managers with a guideline on how to focus on their brand elements to sustain and enhance their identity.

This paper is structured as follows in the current study outlines: 1 . The theoretical background of a corporate heritage brand, corporate heritage, corporate heritage brand identity and corporate heritage brand traits. 2 . The research methods that are used to develop the research framework. 3. The results are presented. 4. The research contributions and limitations as well the future research suggestions.

\section{The THEORETICAL FRAMEWORK}

\section{The notion of corporate heritage brand identity}

Corporate heritage brand is a new concept that was introduced in the mid of 2000 s. Balmer and others introduced the first article about corporate heritage brand in 2006. It defines the corporate heritage brand concept and introduces the main dimensions of the corporate brand idea. Balmer used the case of the British monarchy as a corporate heritage brand (Balmer et al., 2006). Urde, Greyser and Balmer introduced a second paper on corporate heritage identity in 2007; this paper develops and clarifies their approach that was introduced in 2006 to explain more about the phenomenon of 
heritage brand by considering several heritage brand cases. Urde and others describe that longevity is important to show heritage, while antiquity is not enough to meet heritage brand criteria. They suggest that a heritage brand needs more focus and attention from brand management because it is unique in terms of the value and the experience it carries with it.

Several scholars have given attention to the corporate heritage brand concept due to its value in keeping an old brand powerful; their research shows how experience and knowledge keep the heritage brand in a leading position in the market. Several scholars have worked to explore this topic and develop the literature gap on defining the corporate heritage brand concept such as Balmer et al., 2006; Balmer, 2009; 2011a; Blomba“ck and Brunninge, 2009; Hudson, 2011; Hudson and Balmer, 2013; Schroeder et al, 2015; Santos et al., 2016; Wiedmann et al., 2011;Urde et al., 2007.

By reading Urde and other papers, which explain the phenomenon of the corporate heritage brand, the author has noticed that heritage brand has a "track record" which covers a positive history of serving the customer. It must also commit to delivering a "Core value". Heritage brand must have a "Symbol" to identify the brand it reflects. Finally, corporate heritage brand signifies the time stream, which keeps the heritage brand "longevity" and shows the heritage brand continuity.

In other words, corporate heritage brand as Balmer clarifies reflects the history that stakeholders have communicated about the corporate brand (Balmer, 2011b). A corporate heritage brand tells a story about the brand and shows its history. It is not as others might consider that corporate heritage and brand heritage are linked to cultural heritage (Burghausen and Balmer, 2014; Hakala et al., 2011; Ko and Lee, 2011). Heritage reflects the core value that gives the continuity and also it shows the history of being respected (Hudson, 2011). History becomes a communication channel to external and internal stakeholders with the corporate organisation to explain their promise and shows the strength of the heritage brand (Blomba“"ck and Brunninge, 2009). Sammour's (2017) research defines corporate heritage brand identity as part of a corporate strategy to communicate to a different level of stakeholders together (internal and external). And reflect how price, symbol, quality and design play a role to continue the heritage of the 
corporation that makes their brand identity powerful. The finding reflects the power of brand innovation as a moderator to enhance the relationship between corporate heritage brand identity and corporate heritage brand experience. The research suggested testing Balmer (2013) traits to confirm the main characteristics of corporate heritage brand identity which influence the consumers and stakeholders in the highstreet retail industry.

In a similar vein, Hakala et al. (2011) suggest that brand heritage is a multidimensional concept that can cover history, continuity, reliability, values, and symbols. In addition to that many brands have heritage but most of them cannot be considered as a heritage brand. Corporate heritage brand is defined by Urde et al. (2007) as "a dimension of a brand's identity found in its track record, longevity, core values, use of symbols and particularly in an organisational belief that its history is important" (Urde et al., 2007, p. 4). Corporate heritage brand is clear to the researcher by considering it is the value which covers the brand in heritage character.

Several scholars have given their attention to this topic (corporate heritage brand identity) due to its importance, and they recommend focusing more on its impact on the organization strategy. Table 1 shows a summary of the research that is published.

\begin{tabular}{|l|l|l|}
\hline \multicolumn{1}{|c|}{ Author } & \multicolumn{1}{|c|}{$\begin{array}{c}\text { Year of } \\
\text { publication }\end{array}$} & \multicolumn{1}{|c|}{ Conclusion } \\
\hline Balmer et al. & 2006 & $\begin{array}{l}\text { An empirical case on British Monarchy, it gives an } \\
\text { introduction about CHBI, in addition to that it } \\
\text { clarifies corporate heritage brand characteristics. }\end{array}$ \\
\hline Urde, Greyser 2007 & $\begin{array}{l}\text { The disquisition defines the heritage brand based on } \\
\text { a field case; the results suggest that heritage brand } \\
\text { identity found in core values, use symbols, track } \\
\text { record, longevity, and history. Also, the study } \\
\text { concludes the importance of identity to build a } \\
\text { heritage brand. In addition to that how the } \\
\text { management plays an important role to sustain, }\end{array}$ \\
\hline
\end{tabular}


protect and maintain their corporate heritage brand identity.

A case study on the British monarchy. This $\mathrm{s}$ clarifies the management role in keeping and buil continuity for their corporate heritage brand ider The paper reflects the corporate heritage brand ide requesting a relationship between the heritage bi and the stakeholders.

\begin{tabular}{|l|l|l|}
\hline Wiedmann et al. & 2011 & An empirical study for the consequence of bl
\end{tabular}
heritage on customers toward a corporate brand results suggest the effects of customers' attitudes behaviours on heritage brands.

\begin{tabular}{|l|l|l}
\hline Balmer & 2013 & $\begin{array}{l}\text { Balmer's general review paper. The work revi } \\
\text { corporate heritage domain and introduces a c } \\
\text { definition and the characteristics of corporate herit } \\
\text { The findings request from corporate heritage b। } \\
\text { managers to focus more on their heritage b। } \\
\text { identity and communicate with their stakeholder: } \\
\text { showing their core values. }\end{array}$ \\
\hline Burghausen and & 2014 & $\begin{array}{l}\text { The empirical study focuses on corporate herit } \\
\text { identity nature which would help the managers } \\
\text { corporate identity management purposes. A case s } \\
\text { of a brewery of heritage entities in Britain. }\end{array}$ \\
\hline Urde and Greyser & 2015 & $\begin{array}{l}\text { A field study on the Nobel prize case to understand } \\
\text { approve the identity of a corporate heritage brand. }\end{array}$ \\
\hline $\begin{array}{l}\text { Cooper, Merrilees, } \\
\text { and Miller }\end{array}$ & 2015 & $\begin{array}{l}\text { The study identifies several core differences in how } \\
\text { each type of corporate brand manages corporate }\end{array}$ \\
\hline
\end{tabular}




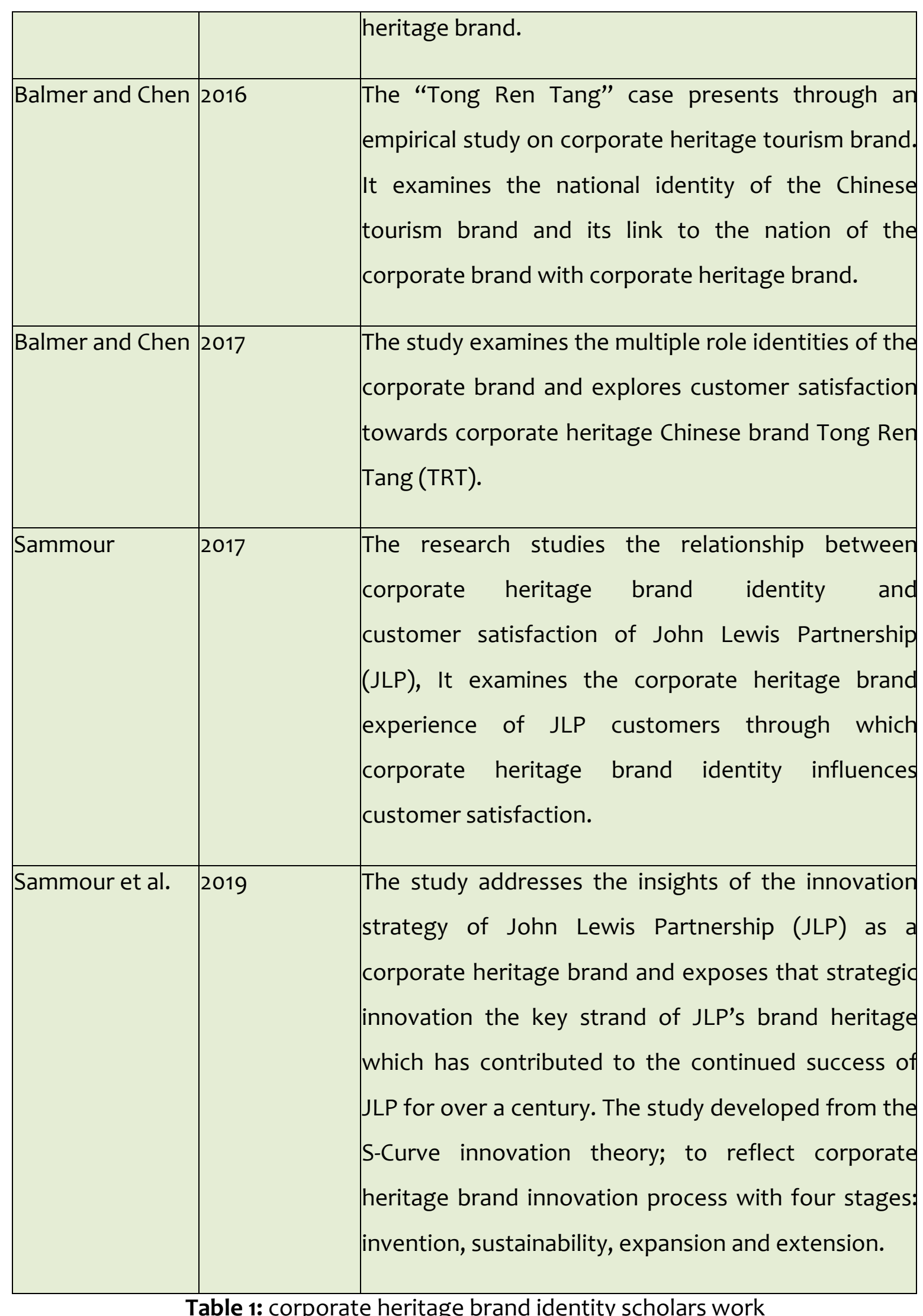




\section{Balmer's corporate heritage brand traits}

According to Balmer's work (Balmer, 2013), corporate heritage characteristics can implement on brands to give them a unique identity.

(1) Omni-temporality is essential to show the time levels (the past, present, and prospective future) that reflect the brand history

(2) Institutional trait consistency which shows the continuity of the corporate brand trait, such as a sign, symbol, feature, and quality.

(3) Tri-generational hereditary suggests that a brand is sustained during a minimum of three generations.

(4) Augmented role identities, corporate heritage brands must consider the importance of showing their identity. A corporate heritage brand must adapt to multi-types of identities such as regional, culture, social, and heritage identities.

(5) Ceaseless multigenerational stakeholder utility is important for continuity by understanding the generations and keeps the corporate heritage brand valid and acceptable for all generations.

(6) Unremitting management tenacity requires strong management to handle and take care of the corporate heritage brand.

Balmer (2013) explains that corporate heritage is about long-term commitment and continuity. His article covers stakeholder's loyalty, identity, flexibility, and profitability. However, several researchers define the corporate heritage as the core of any organisation because it presents their past success and shows their present development and continuity (Greyser, 1997; Balmer and Chen, 2015; Urde and Greyser, 2015). It will also continue to the present to show their prospecting future which is innovated and developed to keep the heritage for their corporation (Balmer et al., 2006). 
Back to Greyser's (1997) article, he agrees that heritage is one of the important features for organisation development in corporate marketing levels. From our point view, it continues the relationship between the stakeholders and the organisation that might be destroyed over time which both Balmer and Greyser (2006) highlighted.

Scholars believe that corporate heritage means that an organisation has assets (Burghausen and Balmer, 2014; 2015; Hatch and Schultz, 2001); this why most companies consider having a corporate heritage to add value to them. Corporate heritage adds for both the companies and their stakeholder's positive values. Companies started to maintain and communicate their corporate heritage with their stakeholders to increase their identification with them (Wilkinson and Balmer, 1996; Balmer, 2009). Balmer (2011a) discusses the corporate heritage that it is not valid only for a single time. Corporate heritage is a multi-time process that reflects the past, the present and the prospective future of company strategy which gives the power for the brand to continue and sustain.

Corporate heritage is powerful as Balmer (2013) explains, it presents multiple identities of heritage that effect multi-generations. Corporate heritage is giving the companies an identity heritage frame and increasing stakeholder loyalty. It also adds value to the corporation and shows its saliency, profitability, and adaptability (Balmer, 2011a; 2013).

The first measure for corporate heritage is Omni-temporality. It reflects the three-time frames: the past, present and prospective future that prove the heritage. Corporate heritage is "multiple time stratums" as Balmer (2011a; b) explains. An organisation understands that heritage is linked to time (Balmer and Chen, 2015). Russell gave a clear statement about time that can reflect the heritage of any corporation. He said that: "The present of things past is memory; the present of things present is sight; and the present of things future is expectation" (Russell, 1957, P.345). The Institution trait constancy shows the organisation stability, it represents via 11 key traits that reflect the corporate heritage as Balmer (2013) explains. These 11 traits that corporate heritage must have two or more to identify the heritage brand are: (1) ownership; (2) organisational-type; (3) organisational rationales cultures and ethos; (4) product and service focus; (5) manufacturing processes and the delivery of services; (6) quality levels; (7) location; (8) 
group and class associations; (9) design and style; (10) sensory utilisation; and (11) corporate communications (Balmer, 2013; Urde et al., 2007).

Tri-generational hereditary is the 3 rd criteria that reflect a minimum of three generations within 50 years. Corporate heritage must present the past, present and the future. It is "forward with the past" as Balmer (2013) says. The 4th criteria are augmented role identities, Balmer (2011a) clarifies that corporate heritage must attract different identities such as ancestral, time (temporal), place, culture, social and regional identities.

Corporate heritage is multi-identities, which lead any organisation to give more attention to it and believe it (Balmer, 2011a). Ceaseless multigenerational stakeholder utility is important for the organisation to build its corporate heritage continuity. Corporations must ensure that the multi-generation of stakeholders are treated professionally, and concentrate on different generations to keep the unity of the corporate heritage.

Balmer (2011a) gives three instructions to enhance trust between stakeholders in multigenerations with the organisation. These instructions that the corporate heritage should follow are continuity in meeting the needs of multi-generations of stakeholders, keeping the entity attentive and the nature to attract the multi-generations stakeholder's, and finally to ensure the originality and the uniqueness of the corporate heritage (Balmer, 2011a).

The 6th criteria explain unremitting management tenacity, which is really important to show and maintain corporate heritage. Managing the corporate heritage is essentially a request as Balmer (2011a) and Urde et al. (2007) discuss to continue the stability of any corporation.

The success of any corporation requests strong management to continue what was built in the past and its need also a focus to extend it to be valid in the future. The corporate heritage brand managers need full support and cooperation from all management levels; to target the multi-stakeholders in different generations and demands toward building brand loyalty. This will show the corporate heritage values and sustain the strategic effort that management is building to develop their corporate heritage brand. All the above criteria that Balmer (2011a, 2013) considers to be important will continue the success of any heritage corporation. 


\section{Research Method and analysis}

This paper applies a qualitative method approach to discover the nodes and the themes of this study, by grouping them to make a judgment about what are the characteristics of any corporate heritage brand in the high-street retail sector (Patton, 1990, p. 406).

Following a review of the literature on corporate heritage identity and all related academic areas, a qualitative study (using semi-structured interviews) and nonparticipant observations were carried out to develop the theory about corporate heritage brand identity (Creswell, 2007; Palmer and Gallagher, 2007; Yin, 2009). The qualitative method was used to increase the validity of this research and develop the theoretical framework; the researcher used the qualitative approach to justify the literature review findings and supported the main research approach through using quantitative methods (Robson, 2002).

This paper identifies the characteristics of corporate heritage brand identity which could be applicable to any (retail brand). Moreover, these characteristics were collected from several pieces of literature on corporate heritage and corporate heritage identity to be tested and measured through semi-structured interviews with corporate heritage brand stakeholders (Rubin and Rubin, 2011). These studies permit more understanding and clarification of these characteristics, and also provide feedback and suggestions that might help to build an understanding of this study. A single case study was carried out for this research to clarify the initial review of the literature and identify the John Lewis corporate heritage brand case through the context in the literature about the corporate heritage brand identity (Yin, 2009).

As one of the main corporate heritage retail high-street brands, the John Lewis case represents longevity, authenticity and sustainability in the British retail sector (Sammour et al., 2019). John Lewis partnership is a department store with locations all over the world. Locally, it is a British heritage high street retailer founded in 1864 in Oxford Street London. John Lewis operates through 49 stores across the United Kingdom. 
Furthermore, it is the first corporation to share its revenues with their employees by considering the employees as partners since 1929.

The corporation expanded the mission and the vision to sustain the business profit through corporation relationships between all stakeholders as well as business partners and suppliers in the British retail market during that period. The business strategy was to build a social relationship with the community and customer all over the UK and to grow up the well- known brand. The continuity attracts different generations to involve in developing this business until now.

After over 150 years of success, John Lewis Partnership is considered as a heritage high street retailer in Britain. Internal and external stakeholders consider John Lewis

Partnership as a heritage innovated corporation. The partnership is preserving its past as a successful business story in serving the community. As well they hope to inspire the future by sustaining what was built in the past and develop it at the present time to keep John Lewis at the highest level. John Lewis Partnership has an iconic identity through their success achievement towards its customers. Today, John Lewis Partnership (JLP) operates 49 John Lewis stores across the United Kingdom, as well as 352 Waitrose grocery supermarkets in Britain and abroad.

A single case study was applied in this paper, John Lewis partnership participated in this study to evaluate their corporate heritage brand identity. The researcher spent 67 hours at John Lewis stores to observe their brand traits, 5 different location in the United Kingdom were visited to verify the main themes which identify John Lewis corporate heritage brand traits. Table 2 shows the hours in each store. The observation locations were suggested by John Lewis partnership management, and it was organised by each branch manager regarding the dates and the times. The researchers requested to visit John Lewis travel shop at St Pancras International rail station due to the high demand of a visitor to a small size shop to purchase an authentic gift before leaving the United Kingdom. 


\begin{tabular}{|l|l|l|}
\hline Date & Location & Hours \\
\hline 23.Jan.17 & Kingston & 5 \\
\hline 27.Jan.17 & Brent Cross & 5 \\
\hline 31.Jan.17 & John Lewis St Pancras & 8 \\
\hline 24.Feb.17 & John Lewis St Pancras & 6 \\
\hline 29.Jan.17 & Oxford Street & 7 \\
\hline 17.Feb.17 & Stratford City & 8 \\
\hline 21.Feb.17 & Liverpool & 4 \\
\hline 30.Jan.17 & Leicester & 5 \\
\hline 18.Feb.17 & Reading & 4 \\
\hline 19.Feb.17 & Reading & 5 \\
\hline 11.Feb.17 & Manchester Trafford Centre & 6 \\
\hline 22.Feb.17 & Southampton & 4 \\
\hline
\end{tabular}

Table 2: John Lewis Site observation hours

The researcher organised with John Lewis heritage centre to collect several (face-toface) semi-structured audio-recorded interviews which took place in Cookham the place of the John Lewis heritage centre. The interviews were approached at different levels of stakeholders (Directors, Managers, Employees, retired employees, and loyal customers those who's visiting the heritage centre). The interviews were scheduled to not exceed more than one and a half hours for each participant.

Fourteen interviews were carried out in Cookham during October and November 2016. All participants of the research interview questions were knowledgeable about John 
Lewis heritage brand and organisation which helped the researcher to get the right feedback and information during the interviews (see Table 3).

\begin{tabular}{|c|c|c|c|c|}
\hline $\begin{array}{l}\text { Case } \\
\text { No. }\end{array}$ & Occupation & $\begin{array}{l}\text { Interview } \\
\text { length } \\
\text { (min) }\end{array}$ & $\begin{array}{l}\text { Interview } \\
\text { date }\end{array}$ & $\begin{array}{l}\text { Relation with John } \\
\text { Lewis (Year) }\end{array}$ \\
\hline M1 & $\begin{array}{l}\text { Retired Manager / John Lewis Optical } \\
\text { department }\end{array}$ & $33 \mathrm{~min}$ & 15.Oct.16 & Over than 35 Years \\
\hline CS1 & $\begin{array}{l}\text { Loyal customer recommended by JL } \\
\text { management }\end{array}$ & $29 \mathrm{~min}$ & 15.Oct.16 & Over than 35 Years \\
\hline Cs2 & $\begin{array}{l}\text { Loyal customer recommended by JL } \\
\text { management }\end{array}$ & 3omin & 15. Oct.16 & Over than 35 Years \\
\hline $\mathrm{E} 1$ & Junior Employee / Archivist & $37 \mathrm{~min}$ & $20.0 c t .16$ & Over than 2 Years \\
\hline$M 2$ & Senior Manager / Administrative & $31 \mathrm{~min}$ & 20.Oct.16 & Over than 6 Years \\
\hline M3 & Manager / Corporate communication & $44 \mathrm{~min}$ & 20. Oct.16 & Over than 23 Years \\
\hline SM1 & Director / Business development & $66 \mathrm{~min}$ & 24. Oct.16 & Over than 39 Years \\
\hline M4 & Retired Employee / Reading Store & $45 \mathrm{~min}$ & 29.Oct.16 & Over than 50 Years \\
\hline Cs3 & $\begin{array}{l}\text { Loyal customer recommended by JL } \\
\text { management }\end{array}$ & $29 \mathrm{~min}$ & 02.Nov.16 & Over than 40 Years \\
\hline$S M 2$ & Retired Director / Factory Engineer & $36 \mathrm{~min}$ & 02.Nov.16 & Over than 40 Years \\
\hline M5 & Retired Manager/Head Office & $28 \mathrm{~min}$ & 02.Nov.16 & Over than 40 Years \\
\hline Cs4 & $\begin{array}{l}\text { Loyal customer recommended by JL } \\
\text { management }\end{array}$ & $26 \mathrm{~min}$ & 05.Nov.16 & Over than 60 Years \\
\hline Cs5 & $\begin{array}{l}\text { Loyal customer recommended by JL } \\
\text { management }\end{array}$ & $35 \mathrm{~min}$ & 09.Nov.16 & Over than 40 Years \\
\hline Cs6 & $\begin{array}{l}\text { Loyal customer recommended by JL } \\
\text { management }\end{array}$ & $29 \mathrm{~min}$ & og.Nov.16 & Over than 11 Years \\
\hline
\end{tabular}

Table3: In-depth interviews list 
For this study, the John Lewis partnership heritage centre dedicated a private room for the researcher to talk to all participants, as well as making arrangements for the interviews (Malhotra et al., 2000). The interviews lasted between 45 -75 minutes. Away from the participants views and beliefs in the questions asked, the participants were encouraged to express and talk more about corporate heritage brand indemnity factors.

As Rubin and Rubin (2011) have clarified there are three types of research interview questions: main questions, probing questions and finally follow-up questions. The main questions covered the main topics of the framework. In this research, the main questions gave general feedback regarding the identity, experience, innovation, word of mouth, multiple time dimensions and satisfaction terms for any corporate heritage brand. They gave a full picture of how the interviewees felt and expressed their opinion regarding these terms. The probing questions were asked to obtain more deep information and make the data richer and valuable (Patton, 1990).

It usually gives an indicator to the interviewees about the level of feedback wished for. The follow-up questions were asked after the consequences of the main questions. It gives also a deep understanding of what was discovered, decorates the context of the answers, and discovers the results of what was said and to test. Finally, to adjust the latest explored themes.

After two months with full support from John Lewis heritage centre management, the interviews were completed and the data of the qualitative interviews were uploaded to the NVIVO 11.

After the collected interviews data were clustered into four themes (price, quality, design and symbol), the coding process started. The researchers in this study relied on the ground theory approach (Glaser and Strauss, 1967) in order to complete the coding process. The grounded theory as Corbin and Strauss (1990) defined said: "a qualitative research method that uses a systematic set of procedures to develop an inductively derived grounded theory about a phenomenon" (Corbin and Strauss, 1990, p. 21). 
The researcher read the transcript of each interview carefully to get a general indication of the impact of every interview. This method helps the researcher to understand the interviewee's ideas and feedback before segmenting the speech to start the analysis.

During this stage, notes were taken regarding the relationship between the corporate heritage brand identity and corporate heritage brand experience which leads to customer satisfaction. General themes that appeared in these interviews were helpful in giving clear guidelines to reorganise the research framework and reach an advanced level of data reduction and analysis.

To understand each interview and highlight the main segments and themes, the researcher transcribed all the interview data within a month and started to listen to the audio-recorded file several times to understand deeply the effects of each conversation on this research study. The Interviews were divided into two categories. The first category was the John Lewis employee interviews and the second was the John Lewis retired partners and loyal customer interviews. To organise and control the qualitative data analysis process, the researcher decided to analyse the content of the collected interviews under several separate themes that reflects the corporate heritage brand identity. 


\section{Findings (Results and discussion)}

The findings from the 14 semi-structured interviews discovered the corporate heritage brand identity dimensions that effect on John Lewis heritage retail brand. The four dimensions which give a strong identity for the corporate heritage brand are price, quality, design and symbol.

\section{Corporate heritage brand price}

The price of any product or service is represented by a tangible value that a customer buys or bid to own this product or service. Several researchers have noticed that the price is an important factor to reflect the heritage value of the brand and appear its brand value (Wiedmann et al., 2015; Santos et al., 2016; Liu et al., 2013; Fionda and Moore, 2009).

This study noticed from the above literature the main key factors that might affect the identity of any corporate heritage brand such as competitive price, best deal prices, representing the brand value, affordable, having a clear pricing policy and strong price strategy. The price of any corporate heritage brand must be competitive to other brand prices and affordable to most of the targeted customers. The customer is always searching for the best affordable competitive price at the market to purchase; this leads the customer to identify the brand easily. Aaker (1991 and 2004) explains that to build a strong identity for any corporate brand, the price must be affordable and competitive to somehow represent the value of the brand. Also, Sirdeshmukh et al., (2002) clarify the importance of providing the best deal price to the brand customer. Because the best deal price is playing an important role to build a strong identity with the corporate brand.

Moreover, the brand price strategy must be clear and reflect the heritage of the organisation. This is applicable to apply if the organisation considers the price on their mission and vision statements. Most of the corporate brand organisation at the retail trading market set a clear pricing strategy and inform it to their customers' invoices or purchasing agreement. In this way, the customer feels more confident with this brand 
and it will lead them to build a strong identity between the corporate heritage brand and the price of it. Several brand management scholars support this idea because it reflects the power of the brand (Balmer, 1988; 2010; Balmer and Greyser, 2006; Balmer et al., 2006).

From all these points of view, this research identifies that the price is an important factor for building a strong identity for the corporate brand heritage. This study defines the price of corporate brand heritage as the value that reveals longevity, investment, development and innovation of the service or the product during a long history in dealing with the customer to serve them with the best price. This value shows the strategy that keeps the brand in a good position and reaches to a heritage level. Therefore, this research measures the corporate heritage brand identity through its product and service price.

Corporate heritage brand can be identified by the product or service price as were justified by some scholars (Sirdeshmukh et al., 2002; Liu et al., 2013). Most of the marketing scholars agree that the price plays an important role to build a position for any corporate organisation, and it is been selected as one of the four marketing mix strategy's (Nandan, 2005). Also, it is a part of the organisation strategy to sustain their heritage brand and keep it powerful (Balmer, 1998; 2010; 2013). While the researchers could not find any studies that consider the product or service price as one of corporate heritage brand traits.

Several academic studies discussed how the price of any service or product played an important role to sustain the corporate brand (Balmer, 1998; 2010; Keller, 2009; Wiedmann et al., 2015; Balmer and Grayser, 2006, Aaker, 2004; Fionda and Moore, 2009). This clearly gives a contribution in increasing the understanding of the position that the service or product price participate in building the identity for the corporate heritage brand.

The John Lewis heritage centre director informed the researcher that John Lewis Partnership price identity founded since 1925, and it's a heritage strategy that still works until this moment. She said that: "John Lewis price identity goes back to 1925 when never knowingly undersold introduced, introduced by Spedan Lewis as a means to 
ensure that the buyers would sell their goods by the goods from the wholesaler as a lower price because there will be limited by the amount they could market sell them that then be recognized by customers and has been a strong selling point ever seen." (Case SM1)

Her feedback gives a strong clarification that John Lewis price strategy is founded on the past time, and which is still valid today to provide the best price to John Lewis Partnership brand customers. This strategy leads the customer to identify the JLP brand on the market as well as build a strong relationship with it.

As Aaker's (1991; 2004) research findings show that the corporate heritage price identity symbolises brand quality, performance, brand longevity, and heritage. The corporate communication manager in John Lewis explains their price identity as: "A UK wide brand of department stores, which attempt to offer the best possible product, the best to possible quality, and they attempt to make available the best possible price, I will describe it as a solid middle-class brand." (Case M6)

John Lewis heritage brand is known for its good price and quality. The good price is not affordable to all customer segments; it is targeted only to the middle and upper-class customer.

A number of interviewees (Case $\mathrm{M}_{1}, \mathrm{Cs} 1, \mathrm{M}_{2}, \mathrm{Cs}_{3}$, and $\mathrm{Cs}_{5}$ ) pointed that John Lewis "Never knowingly undersold" slogan became a heritage term which most of retail started to follow on their sales strategy, which gives John Lewis the strength as a founder for this strategy on identifying their brand and organisation.

Customers who approach John Lewis to buy their brands know that they are getting the acceptable price with good recommendation from a John Lewis staff member due to their knowledge and the best service that keeps the customer satisfied as a John Lewis department manager explains: "We supposed to be at least same price if not lower, so getting good value so should be able to coming into the shop knowing that if you are looking for a product that it is available in few other heritage stores, and heritage store I assumed you are talking about thing things like Debenhams, House of Fraser, Harrods for example: most probably our price is the lowest in London area anyway, you know 
that your price could be the same or cheaper and give you that trust if you would find it cheaper in another shop then you can come back and tell John Lewis and within a reason of space and time they give you the difference back." (Case M1)

Through the known price slogan 'Never knowingly undersold' John Lewis is committed to provide the best price to all their customers and have a price match with any other high street store. This gives the customer trust and satisfaction toward the brand.

Since 1925, John Lewis introduced to the retail industry a slogan which became a part of their heritage image: 'Never knowingly undersold'. This slogan is a part of JLP's commitment to introduce the best quality at the best price to the market. A John Lewis manager clarified this iconic heritage theme. "To make a clear statement because we are very conscious of it; since 1925 our slogan has been 'Never knowingly undersold', which for me means offering the best possible product at the best possible price. There is trust between vendor and purchaser. What we are selling we make available, and in the best price we can; not necessarily stocking the cheapest products but always offering the best value." (Case M3)

Several interviewees describe John Lewis price as affordable and very competitive compared to other heritage retail store in the high street market (Case Cs1, E1, M2, M4, and (s5). They explain how the pricing strategy in John Lewis is clear; the John Lewis goods are a valuable and targeting the middle and upper class of the customer segment.

A John Lewis interviewed employee explained how they price strategy to identify them at the retail market by saying: "obviously we price match, we always identify our self in matching so if anyone finds any things cheaper we will allow pricing match that." (Case E1)

Sirdeshmukh and other scholars (2002) explain how brand price plays an important role in maintaining the relationship with the brand-customer to keep the customer satisfied and build their loyalty. A John Lewis loyal customer explains her experience in terms of getting the best price while she had a shopping experience in John Lewis by saying: "We bought some curtain and the price was different in another store, John Lewis went to deal and match the price because the material was in two different names, but they said 
'no' it's the same material and they gave us the lowest price. I think they hit the market in the right place; they are very good in their prices." (Case Cs3)

\section{Corporate heritage brand quality}

Brand quality is one of the main elements that a customer identifies the product or service brand they deal with. Scholars define the brand quality from a customer perspective as the customer judgment of excellence, respect and the advantage of the corporate brand product or service that they are dealing with (Netemeyer et al., 2004). Aaker and Keller also agree that brand quality has a strong impact on leading customers to change their decision once they are looking to purchase or use the brand (Aaker, 1996; Keller, 1993; 1998) whereas a few researchers are focused on highlighting how the quality can be considered as one of the corporate heritage brand traits (Balmer, 2013).

Balmer's (1998) corporate marketing mix dimensions which are called the (11P's) measures the performance of any corporation through the brand quality that they introduce to the market. Performance is considered as one of these dimensions due to the importance of corporate brand quality on a stakeholder's decision to build the identity with these corporate brands (Balmer and Greyser, 2006). The performance of any product or service is part of brand quality which helps to build its reputation in the market.

Balmer in his several papers (1995; 2001a; 2001b; and 2012) discusses that the success of any corporate brand service identity must be delivered through good service and high quality. Lam et al. (2012) and Corkindale and Belder (2009) agree that corporate brand quality is important in building a brand identity. These results explain the important role of the brand quality on building a reputation in customers' minds and engaging them strongly toward the brand. The sustainability of any corporate heritage brand is an outcome of keeping the heritage brand in a high-quality standard. Several researchers support this idea because heritage brand means that this brand has a strong experience and success in the market that was established in the past time and is now valid and 
innovated in the present time. Also, there are plans to continue and develop in the future (Pappu et al., 2005; Yoo et al., 2000).

With all these developments and innovation in products and services, customers these days are selective to purchase a high-quality standard of brands that sustain a long time. Corporate brand quality might be tangible or intangible. Also, brand quality

measurement leads to stockholder satisfaction and corporate brand success. Moreover, organisations manage the quality of their heritage brands based on their plan and strategy toward their corporate heritage brand identity. In addition to that, they can sustain the quality progress or they might ignore it based on their corporate heritage brand strategy (Wallström et al., 2008).

Corporate heritage brand quality identity in most of the literature suggests the importance of the brand quality in building the corporate heritage brand identity (Balmer, 1998, 2012, 2013; Lam et al, 2012). In addition to that, several types of a research study the relation between the quality and heritage brand identity and they recommend sustaining the success of building high-quality standard and continue in developing the corporate heritage brand (Pappu et al., 2005; Yoo et al., 2000). The interviews of this study tried to identify John Lewis heritage brand quality, the researcher noticed that most of the interviewees agreed in a high standard of quality that John Lewis partnership committed to introduce in the retail high street market (Case $M_{1}, C_{2}, E_{1}, M_{2}, C_{3}, M_{5}$, and (s6).

A John Lewis corporate communication manager identifies John Lewis as: “A UK wide brand of department stores, which attempt to offer the best possible product, the best to possible quality." (Case M3) This reflects how John Lewis looks to its brand identity, which suggests Blamer's (2013) corporate heritage brand traits. Balmer (2013) considers the brand quality as a part of the institution constancy trait which is important for keeping the brand sustained in the market as (Balmer and Grayser, 2006; Balmer, 1995; 2001a; 2001b; and 2012) explain.

John Lewis gives high attention in keeping their brand durable to show their longevity in serving their customers with the best quality that sustain their brand. As several scholars suggest the importance of keeping the heritage brand durable and well maintained 
(Aaker, 1991; Pappu et al., 2005; Yoo et al., 2000). A retired JLP Factory Engineer director said: "The quality means what ultimately the goal of our customers, so they need to see it durable, feels good, very attractive and can be used for some time not today also the other day. The product of John Lewis tested in the laboratory before selling it to the customers from several points, light fastness, wash fastness, durability and shrinkage, and it must be below standard."(Case SM2)

Providing customers with a long time of brand warranties gives an indication for the brand customers how this brand is strong. Also, it shows that the brand is well developed and tested as several scholars discuss (Aaker, 1991; Netemeyer et al., 2004). Cases (M1, Cs1, M3, and M5) explain that a customer can identify John Lewis white goods from other goods in the retail market due to the more warranty years they provide to the buyer. The standard manufactory warranty for most white goods is 3 years while John Lewis offers for its own brand 5 years.

The heritage centre director in John Lewis explains that John Lewis as a heritage corporation delivers a high-quality standard at a reasonable price that a customer can own such a brand. She mentions that: "John Lewis brand quality is perceived to be of above the standard product, it is not classed as the luxury it is supposed to be the best quality you can get for a reasonable price, what reasonable is: is its tie to customer decides."(Case SM1)

This clearly reflects the covenant that John Lewis provides to their customer in terms of building a satisfaction with the brand and sustaining the good reputation that was founded since 1864 .

During the interview with a John Lewis loyal customer who has a long experience with $J \mathrm{~L}$ brand for over that 50 years. She explained about their experience with John Lewis brand quality and how John Lewis brand is strong to deliver her happiness by saying that: "I never had an argument about their quality, if I bought any things I didn't have reason to complain about it, it is doing well, I used it for a long time and their standard makes me quite happy. The quality is pretty good, looking presentable, hard-working; it does the job that it's meant to very well." (Case Cs4) 
The above statement clearly shows how John Lewis partnership builds a strong reputation on his customer's mind, the brand is transferred from its tangible or intangible position to be a source of happiness to the customer. This completely reflects the importance of brand quality on building the identity to any corporate heritage brand.

John Lewis partnership gave their product or their service big attention to be under a unique standard; a retired director who is responsible for managing one of the owned factories that produce fabric to John Lewis explained to the researcher the mechanism that John Lewis sets to test their product quality. The founder John Spedan Lewis believed in giving his customers the full care, so he reflected that on any service or product that he introduced to the customers.

Another loyal customer who is aware of technology and innovation explained to the researcher how John Lewis partnership quality is maintained, he concluded his words by saying it is a reliable brand: "as I said before about the quality of their products, they generally have very good quality. They made well, and to cover this term (Made well) I think it covers a lot of different topics; it's about physical, manufacturing, design, it about functionality as well. I am sure it is reliable, they choose the right products that have done and introduced in the right way: it is not flimsy or plastic, they do things probably (properly)."(Case Cs6)

John Lewis Partnership brand is produced to survive; it is a reliable brand that customers can ensure that it will last longer compared to any other retail brand.

As a result of the above discussion, this study defines the quality of corporate heritage brand as providing and maintaining a reliable, durable and excellent feature for any corporate product or service. In addition to that, the work reflects the heritage brand experience in building a high standard for this brand during the time. The second measurement that this research justifies is that any heritage brand must provide the best brand quality to build its corporate heritage brand identity. Also, this suggests that brand quality plays an important part in building a reputation for the corporate heritage brand during the time. The high standard of a quality brand is building a strong relationship between corporate heritage brand stakeholders and the corporate heritage brand itself, which will lead to a strong identity. 


\section{Corporate heritage brand Design}

Brand design is defined as how the corporate organisation attracts its customers by its look, function and value. Walsh et al. $(2010,2011)$ research define the brand design as the brand shape, type font, style and colour which represent the brand name, symbol and sign to identify this brand rather than another brand. Moreover, several scholars give the brand design attention to build corporate brand image (Balmer, 2008; Hatch and Schultz, 2001; Urde, 2003; Kathman, 1999; Aaker, 1997). Brand design scholars notice that corporate brand must have a high standard of design to reflect its elegant, modernity, fashion, uniqueness and elegance (Olins, 1978).

The corporate heritage brand is sustained at the market because of its high standard of design. The design of any corporate brand reflects the experience of being on the market and dealing with the customer. During the time, the brand design developed to match different customer needs as well have its own design identity. This design identity gives a standard character for the brand style, colour, or even shape. Jaguar Cars, since 1922 they produced a classic luxury car in a high standard design that has continued for over 90 years. Aaker (1997) and Keller (1993; 2001) agree on the importance of having a high standard of design to build an identity for the corporate heritage brand.

Balmer's (2013) considers the style and design for any corporate brand as a trait for their heritage brand identity and agrees in the importance of keeping the brand design attractive and recognisable to build an identity for the brand. Urde (2003) gives an example of (Volvo) cars by how they build their corporate brand identity through attractive unique designs which are considered as "extended core value". Urde and others refer to it in their papers as one of the heritage identity elements that effect the brand (Urde et al., 2007).

Back to the brand definition, the design must carry all brand aspects which leads to identifying the corporate brand and reflects its importance for the corporate organisation. All the above terms (innovative, recognisable, creative, iconic, unique, and 
attractive) are used to give the corporate heritage brand design a powerful identity (Fionda and Moore, 2009).

The corporate heritage brand design is considered as one of the main corporate heritage brand traits as Balmer (2013) discuss. Also back to Urde (2003) and Urde et al. (2007) work the corporate brand design is a key element for brand core values which build the identity of the corporate heritage brand. Corporate heritage brand design should be powerful, creative and innovative to sustain the brand at the market. This means that heritage brand design must not reflect the old-time, but it reflects the years of experience and practice to serve different styles in different multiple time frames (Balmer, 2011a,b; Hudson \& Balmer, 2013).

The corporate heritage brand design must be recognisable as cited by different brand design authors (Nueno and Quelch, 1998; Alleres, 2003; Oknokwo, 2007; Fionda and Moore, 2009). Cases (M1, Cs2, E1, M4, and Cs6) agree that the John Lewis partnership brand is recognisable; it targets the majority of middle-level class customers. The secondary data that was collected through the researcher's visits to the John Lewis partnership heritage centre gave a clear vision of how John Lewis design was and is still recognisable. The piece of fabric that was used in the RMS Titanic the British passenger's rooms, where one of the designs that John Lewis sells today to demonstrate the heritage design in a modern, authentic, and creative manner. This clearly reflects that heritage designs can be used today and will be used tomorrow if they are designed well.

A John Lewis loyal customer suggests that heritage designs can be used anytime, as she says that: "Some of John Lewis designs are very old but you can see them working now because it is quite a fashion, some other designers are coming out with similar things now... it is a timeless design, it inputs of skilled worker produces these brand. There is a lot of variety if you purchase John Lewis towels today and we look them 10 years' time you they don't understand them being are out of state."(Case Cs1)

Both Arnault (2000) and Alleres (2003) clarifies the importance of keeping the brand design creative. In addition to that, Oknokwo (2007) adds to brand design characteristics the uniqueness as a term which attract the customer and reflect the best brand production. During the interview with a John Lewis administrative manager, she 
explained what she thought about John Lewis' brand since her experience exceeds 20 years at John Lewis partnership. She clarifies how their brand is unique by saying that: "I think we have to have a balance of uniqueness in our design as well as following the current trend and be up-to-date." (Case M2)

Moreover, a John Lewis corporate communication manager informed the researcher that John Lewis has a special and unique designs theme represented on their shop's layout, bags, and fabrics. He says that: "I think in terms of how we design packaging, shopping space, and our online interface, I think the design is on the stated clearly, clarity, elegance, efficiency. I think of the product we sell we design select me to feel contemporary and classic." (Case $\mathrm{M}_{3}$ )

Now a day's John Lewis has started to cover some of their newly renovated shops with some of the heritage fabric and textile designs such as John Lewis Leicester, Leeds and Westfield White City London. These types of heritage designs architecture give the viewer more attention to recognise the store as Case (M2 and $\left.M_{3}\right)$ discuss.

John Lewis these days sells several luxury brands which identify them as one of the British high-street luxuries retails due to the luxury designs that are sold in their stores. The heritage centre director explained that John Lewis since 1864 until today thinks outside the box and believes to serve the customer and deliver the requested needs in the main time that also will be valid in the future. She says regarding John Lewis brand design that: "John Lewis worked with some of the best brightest new designers in the market; they are always looking at what is going on around and outside the business we should beat-up any new unusual ideas, so we will always try something and see if the customer wants and never be afraid to wait until somebody else try it first." (Case SM1)

John Lewis as a heritage corporate retailer in the British high street market believes that their brand must survive because their brand is presenting John Lewis's name and business which was founded over 150 years ago.

A John Lewis retired director who is responsible to manage one of John Lewis fabric factories described during the interview with him John Lewis's design strategy. A few words were repeated from his side which is attractive, creative and valid. He says 
regarding John Lewis heritage brand that: "the design very attractive and acceptable all over the world... there is a design that was printed 150 years still used because of it attractive to the eye, a colour compensation." (Case SM2)

Balmer $(2011 a, b)$ explains that the heritage brand must be sustained for at least three generations, he considers the corporate brand as a heritage if it has a multiple time frame which represents the past time in the present and will continue what is developed at the present in the future time. Therefore, John Lewis customers will always notice the modernity on their designs. A loyal customer who is over 80 years of age with over 60 years of experience in dealing with this brand describes the John Lewis brand design as follows: "John Lewis has a nice design selection and they are usually up-to-date within different age groups, and this is important for ladies from young to old style changes so they found the style that suits their age group this good and important for us as ladies." (Case Cs4)

This paper defines the corporate heritage brand design as the shape, the style or the architecture of any corporate brand that represents its heritage meaning and shows the past in a present way. It reflects the design themes such as attractiveness, innovation, modernity, fashion, uniqueness, and creativity. The third factor suggests that brand design scholars think that a heritage brand design must be unique, to show the brand heritage identity. In addition to that, heritage brand design reflects the longevity of brand experience and the investment that a heritage brand maker has achieved to reach this level of sustainability and continuity for their corporate heritage brands.

\section{Corporate heritage brand Symbol}


Corporate heritage brands have a relation with the symbol of the brand. The symbol carries all the heritage aspects and meanings that give the heritage identity shape for these organisations (Balmer, 2001a; Balmer and Gray, 2003; Aaker, 2004; Balmer, 2005). The sign, the word, the colour and the shape all are some of the best visual attractive communication tools between the brand and the customers (Dowling, 1994). However, Kapferer (1997) define the brand symbol as the tools which are used to differentiate the products and services of the individual company from other companies (Kapferer, 1997).

The symbol of any corporate heritage brand must reflect its multi-generation which shows the past sustaining up-to-date. Urde et al. (2007) research consider the 'use of symbol' as one of the main dimensions of the corporate heritage brand. They explain how the symbol is the state of the corporate heritage brand identity which reflects the successful past time, and the continuity development at the present time. Moreover, the innovation that leads this brand to continue in the future.

Developing the above, brand symbol shows the value of the corporate brand heritage such as sign, colour, shape, stamp or even the word. All these symbol elements help to build the identity of the brand. On another hand, the symbol as a unique value to the corporate heritage brand is going to cost the customer more because it keeps the originality, the luxury, and the attractiveness of the product or the service that carry these symbols as several researchers agree (Aaker, 2004; Olins, 1989; Balmer and Chen, 2015).

The symbol of corporate heritage brand is measured as one of the main dimensions of corporate brand heritage based on Urde, Greyser and Balmer's (2007) thinking. Moreover, Balmer and several scholars explain how the brand symbol builds a unique identity for the corporate heritage organisation (Balmer, 2008; 2012; Balmer and Gray, 2003; Aaker, 1991; 2004; Urde et al., 2007; Erdem and Swait, 2004).

The John Lewis symbol is very recognizable, easily identifiable. It is clear writing representing the founder's name that represents the brand longevity since 1864 . The senior administrative manager in John Lewis partnership says that "The company didn't have change names it has added bits to it; it becomes from John Lewis to John Lewis partnership so our customer can see that all what we were done is grown rather than the 
shrink, John Lewis symbol hasn't been changed, I think it is recognizable you can recognize the John Lewis brand instantly, John Lewis bag instantly, it is so recognizable because of its simplicity. It is unique, Green is quite significant in partnership anyway." (Case M2)

The clear simple logo that John Lewis used to represent their name over their bags, flags or signs reflects their heritage name. Schultz et al. (2000) study explain the importance of the colour to identify the brand. This suggests the manager's speech about John Lewis' unique green colour that was used since the early 1930 s and all the customer satisfaction with it. As a note, the green colour was chosen by Spedan John Lewis the partnership founder. It was his favourite colour using it in his signature and writing and nowadays this colour reflects this partnership which most of the customers can identify it toward this brand name.

During the interview the John Lewis' heritage centre director explains what the word and logo means to the partnership by saying that: "I think both the word and logo have very carefully chosen so both reflect the John Lewis brand, I think they can be used together or they can be used apart, but both of them still have the same value. " (Case SM1)

The logo of John Lewis is unique even if it was changed several times. It was kept to reflect the heritage name of the founder and the value of this partnership. The symbol of John Lewis is always designed to identify them as one of the British high street department stores.

One of John Lewis' retired employees explains the power of John Lewis sign, it is recognisable easily to anybody. She said that: "The company logo is very strong, and part of the logo I would say high street, when you travelling even from the motorway you can identify building the John Lewis sign-on, it is a quite powerful sign, because it's simply two name John Lewis that, of course, the name is powerful John Lewis, short, tailored which is neat." (Case M4)

John Lewis partnership considers their symbol as one of the organisation's identity, their signs cover their store's building to attract customers. This suggests Dowling's (1994) 
approach of how a sign or any symbol element attracts the visual sense for the brand customer, which also builds a communication link between the customer and the brand through a powerful sign symbol. Several cases agree in the strong communication link between the brand symbol and the customers (Cases M1, Cs2, M3, Cs5).

The researcher discussed the John Lewis symbol with one of the retired directors at the partnership. This interviewee has more than 40 years' experience with John Lewis brand in his position as Fabric factory engineering department director. He was arguing since he started explaining that John Lewis has a unique symbol and design. The researcher tried to understand his feedback regarding the symbol colour and shape. And he said that: "the symbol is unique because if you buy a product with that name you will get some sort of guarantee. The colour is very attractive and the people love it if you change the colour I don't think it will succeed so much." (Case SM2)

The symbol plays an important role in reflecting the organisations' identity success. If the organisation fails to build trust and satisfaction with their stakeholders, this will reflect on the brand symbol because customers are sensitive and they notice the symbol with all it is shape. They will remember directly the story bound to this brand. In case (SM2) the interviewee is engaged deeply with the John Lewis corporate brand, he refuses to accept any changes to their symbol.

The name of any corporate brand has a big meaning to all their users, as a word over shopping stores, or logo on the shopping bags; The customer is highly engaged with what they see and recognise, they remember the past directly. A loyal John Lewis customer for over 60 years says the following:: "if I see the logo I feel confident in buying from this brand, I think John Lewis name means to me quality and value, it gives a feeling that it is something that has been for so long, and It was a part of our life." (Case Cs4)

The John Lewis symbol is a part of most of John Lewis customers' life, they feel happy to deal with this brand because of the longevity of the experience of shopping at this department store. This clarifies the research definition of the brand symbol as a communication tool between the brand and the customers to build a strong identity. 
In summary, this study investigated the degree of symbol colour uniqueness, symbol simplicity and identifiably, brand logo recognisability, the heritage of the symbol and finally how the symbol is in the memory of its customers.

The results suggest that corporate heritage brand symbol is the visual communication tools that affect customers or any other stakeholders to engage with the brand and notice the meaning of this brand to build a unique identity with it. Moreover, the symbol of any brand can be represented by shape, colour, word, flag, sign, stamp and mark.

Corporate Heritage Brand Identity Framework Developed from the corporate heritage brand theory (Balmer et al., 2006; Urde et al., 2007) and the results which were collected from observing the John Lewis partnership heritage brand. This study suggests four dimensions for any corporate retail brand which are price, quality, design and symbol as shown in Figure. 1.

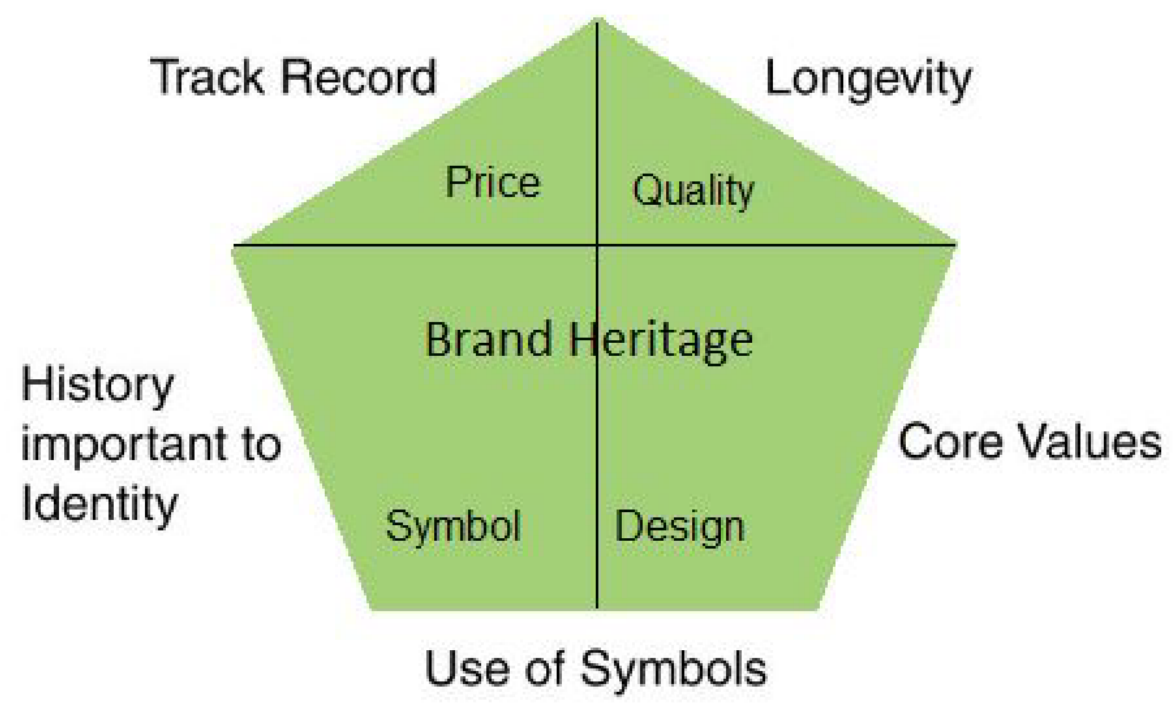

Figure 1: Corporate Heritage Brand traits of this study

We have identified and established the themes and modes of corporate heritage brand identity based on the findings from our JPL case study. The research framework on 
Corporate Heritage Brand Identity (please see Figure 2) is developed from this case study.

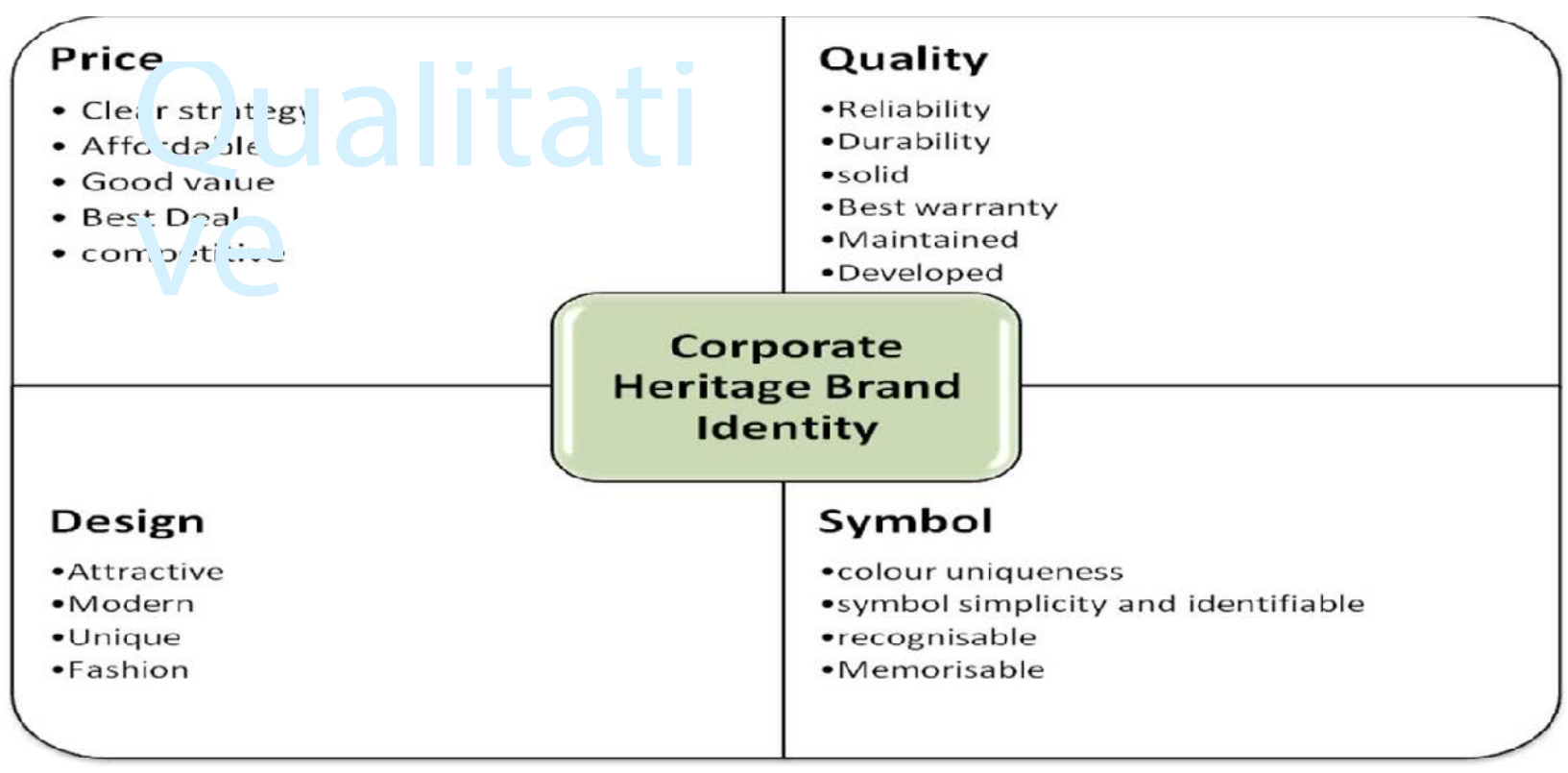

Figure 2: study case framework

\section{Conclusion, contribution and implication for managers}

To support the literature and build the suggested case study framework, fourteen semistructured in-depth interviews were conducted in this study. The interviews were organised through the John Lewis Heritage Centre. The interviewees consisted of John Lewis Partnership directors, senior managers, retired partners, current partners (employees), and loyal customers chosen through John Lewis management. The findings of this research suggest that John Lewis partnership as a heritage British brand has strong identity traits (price, quality, design and symbol) which give it the ability to sustain. This work has contributed to the literature on corporate heritage branding that the framework of corporate heritage brand identity derived and developed from Urde et al. (2007)'s elements of brand heritage. The study tested Balmer (2013) trait's which can be applied to any high-street corporate heritage brand and applied these dimensions to 
Urde et al. (2007)'s framework. Based on the findings from our case study, John Lewis corporate heritage brand identity is a multi-dimensional concept that can be highlighted through their brand price, quality, design and symbol, which are the main four components of our research framework.

Most of the previous studies concentrate on defining the relationship between brand and corporate heritage identity. Scholars reflect on the impact of brand in several fields such as royalty, tourism, family business, heritage and sociality. This research is the first attempt to build an integrative vision of corporate heritage brand traits in a heritage high street origin. The developed corporate heritage brand identity model is significant for researchers and practitioners in the retail field. To the researcher, the corporate heritage brand identity model can be a starting point for further empirical research. Additionally, it is developed from the approach that Balmer et al. (2006) and Urde et al. (2007) defend to build this theoretical base. Since, the corporate heritage brand identity model is created through measurable items it will be easy to test. This research uses the main dimensions that define the corporate heritage brand identity theory (core values, use symbols, track record, longevity, and history) to a specific item that represents the retail brand.

This study model will provide corporate heritage brand managers with a guideline as to how to focus on their brand traits to sustain and enhance their identity to build a powerful brand experience which leads to customer satisfaction.

\section{Limitations and future research directions}

This study makes several contributions to knowledge and extends the literature. This research was restricted by several situations such as theoretical, business environment, culture behaviour, financial, and empirical; all these situations have limited the research. Moreover, this work is one of the pioneering studies which highlights the importance of identity on a corporate heritage retail high street British brand (John Lewis). 
The following points are some of the general limitations of this research.

This study is a continuity for a new business management approach which has been highlighted in the academic field since 2006 by Balmer, Greyser and Urde. The theoretical ground on corporate heritage brand identity is still underdeveloped. Limited research focuses on this topic which restricts the theoretical resources. Scholars have tried to understand several background theories to build this approach and have obtained the finding results.

The business case study of this research (John Lewis Partnership) is critical in terms of market position, privacy, reputation, longevity and image. John Lewis set some restrictions which restricted the research and can be considered as a limitation for the data collection process.

This study has a limited sample due to the time frame that John Lewis imposed on the researcher. As well the limited financial budget that the researcher assigned to spend for collecting the data from the market.

The research results are focused only on one of the heritage retail British brand limiting the research findings. Further empirical research involving data collection over two or more corporate heritage brands is necessary. It will be possible to adapt the same framework on any other heritage retail brand to test and compare the result deeply. While high technology has made a revolution in our lives, netnography as a technological research qualitative technique is suggested to be used in future studies to highlight customer comments and reactions towards brand identity.

\section{References}

Aaker, D.A. and Equity, M.B. (1991). Capitalizing on the Value of a Brand Name. New York. 
Aaker, D.A. (1996). Measuring brand equity across products and markets. California management review, 38(3), pp.102-120.

Aaker, D.A. (1997). Brand equity: la gestione del valore della marca. FrancoAngeli.

Aaker, D.A. (2004) Leveraging the corporate brand. California Management Review, Vol. 46 No. 3, pp. 6-18

Alleres, D. (2003). Competing Marketing Strategies of Luxury Fashion Companies.

Adapted, translated and cited in Bruce, M . and Kratz, C. New York: Elsevier

Butterworth Heinemann.

Arnault, B. (2000). La passion creative. Entretiens avec Y. Messarovitch.

Balmer, J.M. (1995). Corporate branding and connoisseurship. Journal of General management, 21(1), pp.24-46.

Balmer, J.M. (1998). Corporate identity and the advent of corporate marketing. Journal of Marketing Management, 14(8), pp.963-996.

Balmer, J.M. (2001a). Corporate identity, corporate branding and corporate marketingSeeing through the fog. European journal of marketing, 35(3/4), pp.248-291.

Balmer, J.M. (2001b). The three virtues and seven deadly sins of corporate brand management. Journal of general Management, 27(1), pp.1-17.

Balmer, J.M. (2005). Comprehending the Constitutional Monarchies of Britain and Sweden: Issues of Trust and Corporate Brand Management. Bradford University School of Management.

Balmer, J.M. (2008). Corporate brands, the British Monarchy, and the resource- based view of the firm. International Studies of Management and Organizations, Vol. 37 No. 4, pp. 20-45.

Balmer, J.M. (2009). Scrutinising the British monarchy: The corporate brand that was shaken, stirred and survived. Management Decision, 47(4), pp.639-675.

Balmer, J.M. (2011a). Corporate heritage identities, corporate heritage brands and the multiple heritage identities of the British Monarchy. European Journal of Marketing, 45(9/10), pp.1380-1398.

Balmer, J.M. (2011b). Corporate heritage brands and the precepts of corporate heritage brand management: Insights from the British Monarchy on the eve of the royal wedding 
of Prince William (April 2011) and Queen Elizabeth II's Diamond Jubilee (1952-2012). Journal of Brand Management, 18(8), pp.517-544.

Balmer, J.M. (2012). Corporate brand management imperatives. California Management Review, 54(3), pp.6-33.

Balmer, J.M. (2013). Corporate heritage, corporate heritage marketing, and total corporate heritage communications: What are they? What of them?, Corporate Communications: An International Journal, 18(3), pp.290-326.

Balmer, J.M. and Chen, W. (2015). Corporate heritage brands in China. Consumer engagement with China's most celebrated corporate heritage brand-Tong Ren Tang: 同仁堂. Journal of Brand Management, 22(3), pp.194-210.

Balmer, J.M. and Chen, W. (2016). Advances in Chinese Brand Management. Palgrave Macmillan UK. Balmer, J.M. and Gray, E.R., 2003. Corporate brands: what are they? What of them?. European journal of marketing, 37(7/8), pp.972-997.

Balmer, John MT. and Weifeng Chen. (2017). Corporate heritage brands, augmented role identity and customer satisfaction. European Journal of Marketing 51.9/10: 1510-1521.

Balmer, J. M., \& Gray, E. R. (2003). Corporate brands: what are they? What of them?. European journal of marketing, 37(7/8), 972-997.

Balmer, J.M. and Greyser, S.A. (2006). Corporate marketing: Integrating corporate identity, corporate branding, corporate communications, corporate image and corporate reputation. European journal of marketing, 40(7/8), pp.730-741.

Balmer, J.M., Greyser, S.A. and Urde, M. (2006). The Crown as a corporate brand: Insights from monarchie. Journal of Brand Management, 14(1-2), pp.137-161.

Blombäck, A. and Brunninge, O. (2009). Corporate identity manifested through historical references. Corporate Communications: An International Journal, 14(4), pp.404-419.

Burghausen, M. and Balmer, J.M. (2014). Corporate heritage identity management and the multi-modal implementation of a corporate heritage identity. Journal of Business Research, 67(11), pp.2311-2323.

Burghausen, Mario, and John MT Balmer. (2015). Corporate heritage identity stewardship: A corporate marketing perspective. European Journal of Marketing 49, no. $1 / 222-61$.

Cooper, Holly, Bill Merrilees, and Dale Miller. (2015). corporate heritage brand management: Corporate heritage brands versus contemporary corporate brands. Journal of Brand Management 22.5: 412-430. 
Corbin, Juliet M., and Anselm Strauss. (1990). Grounded theory research: Procedures, canons, and evaluative criteria. Qualitative sociology 13, no. 1: 3-21.

Corkindale, D. and Belder, M. (2009). Corporate brand reputation and the adoption of innovations. Journal of Product \& Brand Management, 18(4), pp.242250.

Creswell, J.W. (2007). Qualitative Inquiry \& Research Design Choosing Among Five Approaches. Sage Publications. Thousand Oaks, CA.

Dowling, G.R. (1994). Corporate reputations: strategies for developing the corporate brand. Kogan Page.

Erdem, T. and Swait, J. (2004). Brand credibility, brand consideration, and choice. Journal of consumer research, 31(1), pp.191-198.

Fionda, A.M. and Moore, C.M. (2009). The anatomy of the luxury fashion brand. Journal of Brand Management, 16(5-6), pp.347-363.

Glaser, Barney G., and Anselm L. Strauss. (1967). The discovery of qualitative research. Nueva York: Aldine.

Greyser, S.A. (1997). Janus and marketing: The past, present, and prospective future of marketing.

Hakala, U., Lätti, S. and Sandberg, B. (2011). Operationalising brand heritage and cultural heritage. Journal of Product \& Brand Management, 20(6), pp.447-456.

Hatch, M.J. and Schultz, M. (2001). Are the strategic stars aligned for your corporate brand". Harvard business review, 79(2), pp.128-134.

Hudson, B.T. (2011). Brand heritage and the renaissance of Cunard. European Journal of Marketing, 45(9/10), pp.1538-1556.

Hudson, B.T. and Balmer, J.M. (2013). Corporate heritage brands: Mead's theory of the past. Corporate Communications: An International Journal, 18(3), pp.347-361.

Kapferer, J.N. (1997). Strategic brand management: creating and sustaining brand equity long term, 2. Auflage, London.

Kathman, J.C. (1999). Brand Design Imperatives for Emerging Global Markets. Design Management Review, 10(4), pp.53-59.

Keller, K.L. (1993). izing, measuring, and managing customer-based brand equity. The Journal of Marketing, pp.1-22.

Keller, K.L. (1998). Strategic brand management: Building, measuring, and managing brand equity. New Jersey. 
Keller, K.L. (2001). Building customer-based brand equity: A blueprint for creating strong brands.

Keller, K. L. (2009). Building strong brands in a modern marketing communications environment. Journal of marketing communications, 15(2-3), 139-155.

Ko, E. and Lee, S. (2011). Cultural heritage fashion branding in Asia. In Tourism Sensemaking: Strategies to Give Meaning to Experience (pp. 89-109). Emerald Group Publishing Limited.

Lam, S.K., Ahearne, M. and Schillewaert, N. (2012). A multinational examination of the symbolic-instrumental framework of consumer-brand identification. Journal of International Business Studies, 43(3), pp.306-331.

Liu, G., Eng, T.Y. and Ko, W.W. (2013). Strategic direction of corporate community involvement. Journal of Business Ethics, 115(3), pp.469-487.

Malhotra, N.K., Birks, D.F. and Experian Information Solutions Inc. (2000). Marketing research: an applied approach. Financial Times, Prentice Hall, Harlow

Nandan, S. (2005). An exploration of the brand identity-brand image linkage: A communications perspective. Journal of Brand Management, 12(4), pp.264-278.

Netemeyer, R.G., Krishnan, B., Pullig, C., Wang, G., Yagci, M., Dean, D., Ricks, J. and Wirth, F. (2004). Developing and validating measures of facets of customer-based brand equity. Journal of Business Research, 57(2), pp.209-224.

Nueno, J.L. and Quelch, J.A. (1998). The mass marketing of luxury. Business Horizons, 41(6), pp.61-68.

Okonkwo, U. (2007). What's in a name? The history of luxury fashion branding. In Luxury Fashion Branding. (pp. 13-58). Palgrave Macmillan UK.

Olins, W. (1978). The corporate personality: An inquiry into the nature of corporate identity. Mayflower Books.

Olins, W. (1989). Corporate identity. Thames \& Hudson. London.

Palmer, A. and Gallagher, D. (2007). Religiosity, relationships and consumption: a study of church going in Ireland. Consumption Markets \& Culture, 10(1), pp.31-49.

Pappu, R., Quester, P.G. and Cooksey, R.W. (2005). Consumer-based brand equity: improving the measurement-empirical evidence. Journal of Product \& Brand Management, 14(3), pp.143-154.

Patton, M. Q. (1990). “Qualitative evaluation and research methods”. SAGE Publications, inc. 
Robson, C. (2002). The analysis of qualitative data. Blackwell.

Rubin, H.J. and Rubin, I.S. (2011). Qualitative interviewing: The art of hearing data.

Russell, B. (1957). History of Western Philosophy. George Allen \& Unwin. London and New York, NY.

Sammour, A.A.T. (2017). Corporate heritage brand identity, customer experience and satisfaction: the case study of John Lewis Partnership. (Doctoral dissertation, Brunel University London).

Sammour, A., Chen, W., Balmer, J.M.T., Botchie, D. and Faraday, J. (2019). Crafting the forever now: corporate heritage brand innovation at John Lewis Partnership. Strategic Change, 28(3).

Santos, F.P., Burghausen, M. and Balmer, J.M. (2016). Heritage branding orientation: The case of Ach. Brito and the dynamics between corporate and product heritage brands. Journal of Brand Management, 23(1), pp.67-88.

Schultz, M., Hatch, M. J., \& Larsen, M. H. (Eds.). (2000). The expressive organization: Linking identity, reputation, and the corporate brand: Linking identity, reputation, and the corporate brand. OUP Oxford.

Schroeder, J., Borgerson, J. and Wu, Z. (2015). A brand culture approach to Chinese cultural heritage brands. Journal of Brand Management, 22(3), pp.261-279.

Sirdeshmukh, D., Singh, J. and Sabol, B. (2002). Consumer trust, value, and loyalty in relational exchanges. Journal of marketing, 66(1), pp.15-37.

Urde, M. (2003). Core value-based corporate brand building. European Journal of marketing, 37(7/8), pp.1017-1040.

Urde, M., Greyser, S.A. and Balmer, J.M. (2007). Corporate brands with a heritage. Journal of Brand Management, 15(1), pp.4-19.

Urde, M. and Greyser, S.A. (2015). The Nobel Prize: The identity of a corporate heritage brand. Journal of Product \& Brand Management, 24(4), pp.318-332.

Wallström, Å., Karlsson, T. and Salehi-Sangari, E. (2008). Building a corporate brand: The internal brand building process in Swedish service firms. Journal of Brand Management, 16(1-2), pp.40-50.

Walsh, M.F., Page Winterich, K. and Mittal, V. (2010). Do logo redesigns help or hurt your brand? The role of brand commitment. Journal of Product \& Brand Management, 19(2), pp.76-84. 
Walsh, M.F., Page Winterich, K. and Mittal, V. (2011). How re-designing angular logos to be rounded shapes brand attitude: consumer brand commitment and self-construal. Journal of Consumer Marketing, 28(6), pp.438-447.

Wiedmann, K.P., Hennigs, N., Schmidt, S. and Wuestefeld, T. (2011). The importance of brand heritage as a key performance driver in marketing management. Journal of Brand Management, 19(3), pp.182-194.

Wiedmann, K. P., Santos, C. R., Aiello, G., Donvito, R., Godey, B., \& Pederzoli, D. (2015, June). THE GROWING CHALLENGE OF UNLEASHING THE POWER OF STRONG IDENTITIES VIA BRANDING AND BRAND COMMUNICATION-IS IT THE PRODUCT, THE DESIGNER, THE COMPANY, THE CITY OR COUNTRY BEHIND TO ACHIEVE AND SUSTAIN SUCCESS IN FASHION MARKETING?. In 2015 Global Fashion Management Conference at Florence (pp. 799-800).

Wilkinson, A. and Balmer, J.M. (1996). Corporate and generic identities: lessons from the Co-operative Bank. International Journal of Bank Marketing, 14(4), pp.2235.

Yin, R.K. (2009). Case Study Research, Design \& Methods. 4th ed.

Yoo, B., Donthu, N., \& Lee, S. (2000). An examination of selected marketing mix elements and brand equity. Journal of the academy of marketing science, 28(2), 195-211. 